\title{
ELECTORAL REFORM IN JAPAN: A COMPARATIVE CONSTITUTIONAL LAW PERSPECTIVE
}

\author{
Kichimoto Asaka*
}

The electoral systems of both Japan and New Zealand were recently reformed, and both states had their first elections under the new regimes in October 1996. This paper considers some features of the two electoral systems from the point of view of the legal context in which the electoral reforms were made and of the main reasons for those reforms.

\section{I . INTRODUCTION}

Recent electoral reforms in New Zealand and Japan have caused a lot of debate and comment. These two democracies introduced similar but different kinds of proportional representation systems. In both countries, every voter has two ballots - one for a single member electoral district, and the other for a party list. In New Zealand, the Mixed Member Proportional (MMP) system - similar to the German system - was introduced in 1993. In Japan, the Supplementary Member (SM) system was introduced for its Lower House, the House of Representatives, in 1994. In each country, the first general election under the new system was held in October 1996.

Similarities and differences of the two reforms were described in detail by Chris Rudd and Taichi Ichikawa. ${ }^{1}$ This paper will discuss the main features of electoral reform in Japan that were fundamentally different from that of New Zealand in terms of motivation and process, and explain that those differences are related to constitutional provisions in

* Associate Professor, Faculty of Law, University of Tokyo. Professor Asaka's visit to New Zealand was made possible by the New Zealand Council for Teacher Education, with the support of the Law Commission. The Centre for Asia/Pacific Law \& Business (CAPLAB), Victoria University of Wellington, was responsible for the organisation and coordination of his research tour, and the presentation of this paper at a public seminar was jointly hosted by CAPLAB and the NZ Institute of Public Law, Victoria University of Wellington.

1 C Rudd and T Ichikawa Electoral Reform in New Zealand and Japan: A Shared Experience? (New Zealand Centre for Japanese Studies, Massey University, Palmerston North, 1994). 
Japan. This approach will show some characteristic features of the electoral system under the constitutional law in New Zealand, which are almost taken for granted.

\section{TWO MAJOR DIFFERENCES}

\section{A The Constitution of Japan 1946}

There are two major points which should be kept in mind when comparing the constitutional law in New Zealand with that in Japan. First, the Constitution of Japan 1946 is the supreme law of the nation. Therefore, any ordinary laws contrary to it are invalid. ${ }^{2}$ It is an American type constitutional law, which incorporates a bill of rights as well as prescribing the structure of the government. The Supreme Court of Japan has authority as the final arbiter of the constitutionality of ordinary laws. ${ }^{3}$ Unlike European type constitutional courts (for example, the Bundesverfassungsgericht in Germany and the Conseil constitutionnel in France), an actual case, or "case or controversy," is necessary for triggering this judicial review of constitutionality.

The Constitution of Japan provides for its own rigorous amendment process. To amend a provision, (1) the proposal must be passed by a majority of two-thirds of all the members of each House of the Diet (Parliament), and (2) it must be affirmed by a majority of all the votes in a popular referendum. ${ }^{4}$ Even this amendment provision may be amended only by this process. This process is more rigorous than the typical entrenchment clause in New Zealand, where a majority of 75 percent of all the members of the House of Representatives or a majority of votes at a referendum is required, and also where the entrenchment clause itself is not entrenched, that is, it may be amended by a vote of a simple majority of the Parliament. ${ }^{5}$

\section{B The Upper House}

Second, the other major difference between the constitutional systems in New Zealand and Japan is that Japan has a bicameral system. In New Zealand, the appointed Upper House, the Legislative Council, was abolished in 1950. Article 42 of the Constitution of Japan 1946 provides: "The Diet shall consist of two Houses, namely the House of Representatives and the House of Councillors." Under the Imperial Constitution 1889,

2 Constitution of Japan, art 98.

3 Constitution of Japan, art 81.

4 Constitution of Japan, art 96.

5 Electoral Act 1993, s 268 entrenches fundamental provisions relating to the term of Parliament, the Representation Commission, the way to divide electoral districts, the right to vote, and the method of voting. A McRobie "The Electoral System" in Essays on the Constitution P A Joseph (ed) (Brooker's, Wellington, 1995), 317. 
there were two chambers: the House of Representatives and the House of Peers. Of course, members of the House of Peers were not popularly elected. ${ }^{6}$ However, once Japanese imperialism had been defeated in the Second World War and the democratic reform had to be implemented, ${ }^{7}$ the peerage could not survive. ${ }^{8}$ The first draft of the Constitution 1946 by General Douglas MacArthur and his staff provided for a unicameral Diet. When Japanese officials in charge of the constitutional amendment insisted on a bicameral Diet, however, American officials did not oppose it, because they did not consider such an arrangement would be an impediment to the democratisation of Japan so long as members of both chambers were popularly elected. ${ }^{9}$ Therefore Japan now has a popularly elected Upper House, the House of Councillors. ${ }^{10}$

However, what function this Upper House should have is difficult to say. Even those Japanese officials who insisted on the establishment of this House gave little consideration to it other than that the bicameral system could prevent radical shift of policy by the check and balance of two houses and was a normal system around the world at that time. ${ }^{11}$ Though Japan retains a monarchy, the rationale of the existence of the Upper House can be no longer based on any undemocratic elements, which provided the basis of the upper houses in the United Kingdom and prewar Japan. Moreover, since Japan is a unitary state, an upper house cannot be sustained on the basis of federalism, which is the main function for the upper houses in the United States and Germany. It has never been claimed - and cannot be claimed so far - that the Upper House was established for the special status of particular groups in Japan, such as an indigenous people, the Ainu.

The Constitution of Japan 1946 provides for the terms of both Houses: four years for the Representatives, though that House may be dissolved before that; six years for Councillors, and there is an election for that House every three years for one half of them (that is, staggered terms). ${ }^{12}$ There is no dissolution of the House of Councillors. Ordinarily, any decisionmaking of the Diet needs the concurrence of both Houses. However, the House of

6 Imperial Constitution, arts $33 \& 34$.

7 H Oda Japanese Law (Butterworths, London, 1992) 32; H Tanaka The Japanese Legal System (University of Tokyo Press, Tokyo, 1976) 642-685.

8 Constitution of Japan, art 14 s 2.

9 K Takayanagi, I Ohtomo and H Tanaka Nihonkoku Kenpo Settei no Katei [The Making of the Constitution of Japan] Volume 1, Documents (Yuhikaku, Tokyo, 1972) 282-283, 310-311, 390-392.

10 Constitution of Japan, art 43.

11 H Tanaka Kenpo Seitei Katei Oboegaki [Some Notes on the Making of the Constitution] (Yuhikaku, Tokyo, 1979) 207-208.

12 Constitution of Japan, arts 45 \& 46. 
Representatives can override the objection of the House of Councillors under some circumstances. That is, when no conciliation in the joint committee of both Houses can be reached, the vote in the House of Representatives will be the decision of the Diet automatically on the matters of budget, approval of treaties, and nomination of the Prime Minister; but for overriding an objection of the House of Councillors on matters of ordinary legislation, the House of Representatives is required to get a second vote by a majority of two-thirds of the members present. ${ }^{13}$ These provisions also set fixed time limits for the discussion in the House of Councillors.

On the other hand, matters such as the number of members of both Houses and their electoral system, are provided by ordinary laws rather than the Constitution itself. ${ }^{14}$ In other words, the electoral system in Japan is not entrenched by the Constitution for the most part, unlike in New Zealand. ${ }^{15}$ Because the Constitution provides that the House of Councillors exerts weaker power than the House of Representatives, but does not indicate why, the main way to differentiate the House of Councillors from the House of Representative is the difference in the electoral system.

\section{THE ELECTORAL SYSTEM IN JAPAN}

Until 1994, the main difference between the electoral systems of two Houses was their constituencies. The members of the House of Councillors are divided into two: prefecturewide elected members and nationwide elected members. Electors have two votes. One is for a prefecture-wide multimember electorate, and another for the nationwide party list. (Until 1982, this nationwide vote was for a particular candidate, too. That is, the nationwide candidates had to campaign all over Japan.) Although the two votes system was adopted for the new electoral system in New Zealand, the way to count these two types of votes in Japan is different from that in New Zealand. Under the Mixed Member Proportional (MMP) system in New Zealand, party list votes determine the proportional composition of parties in the whole Parliament (120 seats). Winners of electorate seats (65 seats in the 1996 election) can get seats first. And then, every party, when it wins a bigger share of the total seats by party list votes than the number of electorate seats of that party, will fill the remaining seats according to the order of its party list. On the other hand, party list votes in Japan decide only the composition of members of the party list segment (100 Councillors). The electorate segment of the election (152 Councillors) is determined independently. It is called the Supplementary Member (SM) system.

13 Constitution of Japan, arts 59-61 \& 67 s 2.

14 Constitution of Japan, arts $43,44 \& 47$.

15 Aboven 5. 
Until 1994, electors had one vote for the election of Representatives. Its electorates were sub-prefecture-wide. That is, most prefectures were divided into two or more multimember electorates. It is called the Single Non-Transferable Vote (SNTV) system. ${ }^{16}$ The electoral reform in 1994 changed the electoral system of the House of Representatives totally. Now each elector has two votes. One is for a sub-prefecture single member electorate, and the other for a sub-nationwide party list. Three hundred Representatives are elected by electorate votes, and two hundred by party list votes. Japan is divided into eleven regions for party list votes. Party list votes are counted separately within each region, and determine only the proportional composition of members of party list segment in that region. ${ }^{17}$ In other words, the SM system was introduced to the House of Representatives, too.

By this reform, the electoral system of the two Houses came to look similar, although Councillors are elected by wider constituencies than Representatives. On the one hand, however, Japan is a unitary state and does not have a federal system. In the history of Japan after the Meiji Restoration in 1868, the central government has exerted so strong a power over the local community that the autonomy of local governments is very weak. Unlike the United States and Germany, in Japan there is little need to keep the balance among prefectures by having a second chamber. On the other hand, in Japan, parties have tight control on their members, and free or conscience votes are almost nonexistent. ${ }^{18}$ In this situation, it is difficult for the House of Councillors to distinguish itself from the House of Representatives. The debates in the House of Councillors are sometimes seen as the duplicate of the debates in the House of Representatives, or worse, as a waste of time and money. Therefore, there are repeated arguments for reforming the House of Councillors, including introduction of free votes and relaxed party control. Some critics have even suggested the total abolition of that House, although it needs a constitutional amendment; but that has never come up on the agenda of the Diet.

16 Both SM and SNTV were examined in The Report of the Royal Commission on the Electoral System in New Zealand: "Towards a Better Democracy" (Government Printer, Wellington, 1986) 29, 33.

17 In Japan, parties are not required to get more than a particular percentage of total votes (a threshold) to get seats in the party list segment in elections of both Houses, whereas $5 \%$ of party list votes or one single-member electorate seat is required in New Zealand. The description in $n 1$ above at $\mathrm{p} 17$ is incorrect.

18 At the floor votes of the Electoral Reform Bill in both Houses, some Representatives and Councillors defied their party position. This was a rare occasion. However, even on such a divisive issue, parties did not allow free votes. 


\section{THE CONSTITUTIONAL IMPLICATIONS OF MALAPPORTIONMENT}

Although, theoretically speaking, the result of proportional representation in an election is compromised under the SNTV or SM system in Japan, compared with the MMP system in New Zealand (where the whole composition of the Parliament is determined only by the second votes for the party list), Japan has escaped from the serious consequences of disproportional representation in the Diet. ${ }^{19}$ Although two major parties, the Liberal Democratic Party (LDP) and the Social Democratic Party (former Socialist Party), tended to get slightly more seats than the numbers for their share of the popular vote, small parties could sustain substantial seats in the Diet. And so long as the dominance of the LDP was unshaken and the Social Democratic Party remained a distant second, it was unrealistic in Japan for a party which got fewer votes than another to command a majority of seats in the Diet. $^{20}$ This situation in Japan is contrasted with that in New Zealand before the electoral reform in 1993. In New Zealand, the main reasons for the reform were: (1) the repeated broken promises by two major parties (National and Labour); (2) the National party could command a majority of seats by fewer votes for itself than for the Labour in 1978 and 1981 elections; and (3) smaller parties, such as the Social Credit Political League in 1978 and 1981 elections, won unusually fewer seats than their numbers of share of the vote. ${ }^{21}$

Rather, Japan has suffered a different chronic problem in the electoral system. That is a disproportional allocation of seats among electorates. Whether it is a multimember electorate system or a single member electorate system, boundary determination and allocation of seats are necessary. This disproportionality is calculated by comparison of the numbers of electors per seat among electorates. In the case of Japan, however, this disproportionality has been very large. The Diet was supposed to adjust it after the decennial census, by reallocating seats according to the numbers of electors in each electorate though usually leaving existing boundaries intact. In the Schedule 1 for the electoral districts of the House of Representatives in the Public Offices Election Law, there was even express provision of a moral obligation on the Diet to review the seat allocation every five years. However, the reallocation legislation tended to be overdue, even though the Diet had not caused this disproportionality by intentional gerrymandering but just by keeping the status quo in spite of the population movement.

19 For a detailed analysis, see Y Shinada "An Evaluation of Japanese Single Non Transferable Vote System: Is Chuu-Senkyoku-Seido 'Semi' Proportional?" (1995) 29 Kobe U L Rev 65.

20 Now that Japan has a major opposition party, the New Frontier Party, there is a possibility that a party could get a majority of seats despite having fewer votes than another party.

21 Above n 16, 14. 
Following American experience, 22 Japanese citizens have repeatedly challenged this disproportionality in court, citing equal protection under the article 14, section 1 of the Constitution. ${ }^{23}$ They claim that one vote in one electorate has less value than one vote in another electorate and that this disproportionality of seat allocation is unconstitutional. Since 1976, the Supreme Court of Japan has allowed such suits praying for annulment of election results to proceed. ${ }^{24}$ In two cases concerning the House of Representatives, the Supreme Court declared the elections unconstitutional. ${ }^{25}$ In other two cases, it found the elections to be unconstitutionally disproportional, though it stopped short of declaring them unconstitutional, allowing the Diet a reasonable grace period for amending the seat allocation. ${ }^{26}$ So far, it seems that the Supreme Court sets the decisive line of constitutionality at a ratio of 3 to 1 , although the Court has not said so explicitly. ${ }^{27}$ In other words, if one electorate has more than three times as many electors per seat as another electorate, the allocation is unconstitutional. ${ }^{28}$ Unlike federal courts in the United States, ${ }^{29}$ however, the Supreme Court of Japan, even when declaring an election unconstitutional, has never annulled the election result and compelled a fresh election, because such a decision causes a constitutional anomaly - the Court virtually orders the Diet to amend the election law, but all incumbent members of the House of Representatives are supposed to be

22 Baker $v$ Carr 369 US 186 (1962); Reynolds $v$ Sims 377 US 533 (1964).

23 "All of the people are equal under the law and there shall be no discrimination in political, economic or social relations because of race, creed, sex, social status or family origin." Article 44, section 2 provides: "The qualification of members of both Houses and their electors shall be fixed by law. However, there shall be no discrimination because of race, creed, sex, social status, family origin, education, property or income."

24 Supreme Court Judgment (Grand Bench) on 14 April 1976, Minshu 30-3-223.

25 Above n 24; Supreme Court Judgment (Grand Bench) on 17 July 1985, Minshu 39-5-1100.

26 Supreme Court Judgment (Grand Bench) on 7 November 1983, Minshu 37-9-223; Supreme Court Judgment (Grand Bench) on 20 January 1993, Minshu 47-1-67.

27 Roughly speaking, this ratio is equivalent to having a $50 \%$ tolerance from quota, if using New Zealand Electoral Act. By the same token, a ratio of 2 to 1 is equivalent to a $33.3 \%$ tolerance.

28 Supreme Court Judgment on 21 October 1988, Minshu 42-8-644 held the election of a ratio of 2.92 to 1 constitutional.

29 In the United States, the "one person, one vote" principle is strictly enforced, especially in the election of the United States House of Representatives. Karcher $v$ Daggett 462 US 725 (1983) held a 0.6984 percent deviation from that principle unconstitutional. 
unconstitutionally elected and should not have legitimacy to legislate any longer. ${ }^{30}$ The Court has never tried to be involved in the reallocation of seats, either.

On the other hand, in the cases involving the House of Councillors, the Supreme Court had been more reluctant to declare an election unconstitutional, even when the disproportionality exceeded a ratio of 5 to 1 and some electorates had more seats than other more populous electorates. ${ }^{31}$ However, the unanimous Court finally held a ratio of 6.59 to 1 to be unconstitutionally excessive. ${ }^{32}$ Still, a bare majority of the Court - eight Justices among fifteen - allowed the Diet another grace period for adjusting the apportionment before declaring the unconstitutionality of the election. The Court has identified the difference of the election of the House of Councillors from that of the House of Representatives in its prefecture-wide electoral districts, in addition to its staggered terms. It has held that the proportionality might be compromised by the legislative policy and technicality for preserving the character of Councillors as representatives of the whole prefecture. It means that the Court allowed the Diet a wide, although not unlimited, discretion to take the integrity of the status of prefectures into consideration when it allocates the seats of Councillors. ${ }^{33}$

\section{$V$ THE REASON FOR ELECTORAL REFORM}

Although the usually low-key Supreme Court of Japan ${ }^{34}$ is actively involved in this field, challenging disproportionality in court by relying on a constitutional provision is just

30 Section 31 (1) of the Administrative Litigation Act provides a general principle that courts may declare the illegality of actions of administrative agencies without annulling those actions, when they consider the annulment will cause serious consequences to public interests compared with the benefits to the plaintiffs. Although section 219 (1) of the Public Offices Election Law explicitly denies the applicability of this general principle in election law cases, the Supreme Court held that the general principle would control the cases of malapportionment, by interpreting that this inapplicability provision had been expected to control only those cases to upset the particular election results because of illegality in the election process, rather than the unconstitutionality of the whole framework of the election law.

31 Supreme Court Judgment (Grand Bench) on 27 April 1983, Minshu 37-3-345.

32 Supreme Court Judgment (Grand Bench) on 11 September 1996.

33 Above $\mathrm{n} 32$ cited as an example of intentional legislative policy decision the nonexistence of an explicit provision for a moral obligation of the Diet to review the apportionment for the election of Councillors every five years, similar to the provision for the election of Representatives.

34 The Supreme Court has held only three laws unconstitutional other than the electoral law: Supreme Court Judgment (Grand Bench) on 26 September 1974, Keishu 27-3-265 (limiting the punishment of parricide to death penalty and life imprisonment is arbitrarily harsh compared with that of ordinary homicide, and so it is unconstitutionally discriminatory); Supreme Court Judgment (Grand Bench) on 30 April 1975, Minshu 29-4-572 (the regulation to keep pharmacies apart and to disapprove a new entry near the existing one is in violation of the freedom to choose occupations under article 22, section 1); Supreme Court Judgment (Grand Bench) on 22 April 
one means of the recourse available to citizens. So long as, unlike in the United States, the "one person, one vote" principle is not strictly enforced in courts under the name of the Constitution, the Diet itself may, of course, correct this situation just by amending the electoral law. In the New Zealand Electoral Act 1993, the population proportionality is built-in by the statutory formula of allocation of seats and clear range of tolerance up to five percent deviation. ${ }^{35}$ Even in Japan, section 15, clause 8 of the Public Offices Election Law specifically requires the proportionality of allocation of seats for local elections, and this provision is relied on by the Supreme Court for declaring some local elections unlawful, ${ }^{36}$ although it is not clear that the Court means that a specific statutory provision makes a difference to the standard of disproportionality.

In the case of the national electoral system, the Diet had made only cosmetic reforms one after another for this problem, just by adding and deleting seats in disputed electorates. But finally in 1994, there came a chance to have a fundamental correction by electoral reform of the House of Representatives.

The electoral reform in 1994 was within a comprehensive package of political reform, which aimed at eliminating repeated political corruption in Japan. In Japan, the politicians relied on corporate donations for their political activities and campaigns. There was almost no restriction on such donations. However, indiscriminate fundraising made politicians vulnerable to some undue influences. Corporate donations for leading politicians were sometimes indistinguishable from bribery, and political scandals took place repeatedly in the history of Japanese politics, although the public prosecutors always encountered the difficulty of proving that they were bribes rather than political donations. Control of this connection between corporate donations and politicians has been long overdue. At the same time, politicians had complained about the costly election campaigns, where individual candidates had to collect donations and to build their own election

1987, Minshu 41-3-408 (the restriction on the division of forest owned in common is in violation of the guarantee of property rights under article 29, section 2).

35 Section 35 sets the number of seats of the South Island at 16, and the numbers of seats of the North Island and Maori (indigenous people in New Zealand) representation are calculated proportionally according to population. Each Maori elector has to choose which electorate he or she will vote for, a General electorate or an electorate specially reserved for Maori voters (s 76). The number of Maori seats are calculated based on the number of people who opted for the vote in the Maori electorates (s 45). Although this "Maori option" caused a difficult question, this was a matter of statutory interpretation. Taiaroa $v$ Minister of Justice [1995] 1 NZLR 411. By this builtin system, the population imbalance among electoral districts is within a ratio of 1.13 to 1 according to the statistics in The Report of the Representation Commission 1995, at 8. 
machines. Therefore, they wanted to have a change of the electoral system itself to a more party-controlled system.

The political reform package, which originated from recommendations of the Advisory Council on Electoral System (which is convened from time to time and submits reports to the Prime Minister, but most of those reports had been respectfully ignored) in April 1990, consisted of (1) political financing reform for reducing politicians' reliance on corporate contributions; (2) introduction of a subsidy to political parties for clarifying and stabilising political finance; and (3) electoral reform for less costly campaigns where parties rather than individual candidates play the most part.

This electoral reform may have been a matter of political philosophy, too. Some political leaders had in mind a electoral reform for encouraging party competition and political debate. In Japan, the government had been stable under the dominance of the Liberal Democratic Party, and probably so stable that bureaucrats could control policymaking for themselves, without much care for intervention from politicians who were concerned only about their own reelection. Under the former electoral system of multimember electorates, pork which a candidate could funnel into the electorate from the government mattered more than the policy stance of the candidate, because major parties had to have more than one candidates in one electorate and those fellow candidates of the same parties had to compete for votes against each other. Those political leaders considered that, to have sound policy discussions among politicians, there should be two or three competitive political parties and an electoral system suitable for that policy competition. On all accounts, however, proportional allocation of seats was not the main purpose of this reform, but at most an incidental benefit.

After a lot of ado by politicians, political scientists, and journalists, and after political maneuvering, it seems that the final product of the political reform did not satisfy anyone. On the one hand, the political finance reform was compromised and left a lot of loopholes. On the other hand, the component of the subsidy for political parties was kept intact. And the electoral system of the House of Representatives was changed to the Supplementary Member system of single-seat electorates and proportional representation party list. But taxpayers wondered how this mixture of the loose control of political finance, the tax money for political parties, ${ }^{37}$ and the new electoral system would eliminate chronic

37 Although s 4 (2) of the Party Subsidy Law provides for a moral obligation of the parties which receive the subsidies that they should have the democratic and fair constitution and management and other provisions detail about the accounting and disclosure requirements on the expenditure from the subsidies, s 4 (1) prohibits the government from scrutinising political activities of the parties. Even when a party ejected a member by a dubious process, and that member had been supposed to be the next in line on the party list for the House of Councillors to succeed a Councillor who was expected to quit that position soon for running for the election of 
political corruption. At the same time, the problem of disproportional allocation of seats remains to be solved.

\section{BOUNDARY DETERMINATION UNDER THE NEW ELECTORAL SYSTEM}

Under the new electoral system of the House of Representatives, a new commission was established to define boundaries of single-seat electorates. This commission consists of seven members appointed for five year terms by the Prime Minister with the consent of both Houses. The commission submits recommendations for amending electorate boundaries to the Prime Minister after the decennial census and, if necessary, from time to time. The Prime Minister shall respect the recommendation and transmit it to the Diet. The Diet has a final say about the amendment of boundaries. No action on the part of the Diet means that the existing boundaries will continue as they are. This is in part because article 47 of the Constitution provides: "Electoral districts ... shall be fixed by law." Therefore, allowing the determination by the commission to be final and conclusive about electoral boundaries could be an unconstitutional delegation of power of the Diet. As a matter of fact, the electoral districts have been explicitly defined in the schedules of the Public Offices Election Law. In other words, the Constitution demands that the Diet itself be responsible for boundary determination.

To define boundaries, under "The Law Establishing the Commission for Defining Electoral Districts of the House of Representatives," the commission shall take into consideration many rational factors including administrative boundaries, topography, and transportation. On the other hand, the law requires disproportion of population -- not of the number of electors -- between any two electoral districts to be within a ratio of 2 to 1 . However, the task of the commission is only to define boundaries within each prefecture. The law itself sets a mechanism to allocate seats among 47 prefecture. First, one seat is allocated to each prefecture. Then, the remaining 253 seats are allocated proportionally among prefectures according to population.

By this means, less populous prefectures tend to get slightly more seats on the population basis than more populous prefectures. It means that some deviation from a strict 1 to 1 ratio of proportionality is inevitable at this stage. As a matter of fact, even when the new

the House of Representatives, the Supreme Court avoided scrutinising the process and did not disturb the elimination of the member from the party list, because it considered that the autonomy and internal management of political parties should be respected as much as possible even under the proportional representation electoral system. Supreme Court Judgment on 25 February 1995, Minshu 49-5-127. Under s 71 of the Electoral Act in New Zealand, political parties which register for election are required to follow democratic procedures in candidate selection, but how this requirement is enforced is not clear yet. 
electoral system was enacted, the ratio between an electorate in Tokyo (25 seats are allocated) and an electorate of Shimane prefecture (3 seats are allocated) was 1.82 to 1 . So long as the current population movement continues, this mechanism may make impossible the mission of the commission to keep the deviation within a ratio of 2 to 1 . Even when the commission proposed the boundaries in 1994, 28 electoral districts could not keep to the statutory required ratio. After that, newspapers on 10 August 1996 reported that the most recent demographic figures already showed that 52 electoral districts are more than twice as populous as the least populous district, and that the deviation reached as much as a ratio of 2.31 to $1 .{ }^{38}$

In the United States, each state is guaranteed two Senate seats and at least one Representative seat. However, the United States is a federal nation and has a reason to keep the integrity of the state boundaries. In addition, those guarantees are provided in the article 1 of the Constitution of the United States. On the other hand, Japan has little reason to keep intact the boundaries of prefectures which are administrative subdivisions of a unitary nation, even though those boundaries have a historic origin. Moreover, the Constitution of Japan has nothing to say about the guarantee of prefecture-based allocation of seats. It is just a statutory criterion for not exceeding the constitutional limit of equal protection.

Another imperfection of the new electoral system in Japan is that there is no mechanism to reallocate the seats of list members among 11 regions after this new law set the number for each region. The commission has no authority to do it. Schedule 2 of the Public Offices Election Law provides for a self-imposed moral obligation of the Diet to review the allocation after every decennial census. It means that no authority other than the Diet itself will trigger this reallocation, though the same population movement is expected to affect the proportionality of list seats among regions. At the same time, since this electoral reform did not change anything about the election of the House of Councillors, and schedule 3 of the Public Offices Election Law for the seat allocation of that House does not even provide for a moral obligation of the Diet for periodical reapportionments, the reallocation of its seats continues to be made by the Diet at its discretion.

\section{REFERENDUM}

The most important difference in the process of electoral reform between in New Zealand and in Japan was the referendum. In the New Zealand electoral reform, popular will shown by the indicative referendum in 1992, and the binding referendum in 1993

38 On the basis of the number of electors, 63 electoral districts had broken the 2 to 1 ratio by 7 October 1996, the day before the election of 20 October was formally called. The imbalance reached as much as a ratio of 2.32 to 1 . 
played a major role in finalising the reform. The indication of strong support for change by citizens seemed to force reluctant politicians, who had favoured the status quo, to accept the reform. Although even in New Zealand the use of national referendum had been rare until the enactment of the Citizen Initiated Referenda Act 1993, ${ }^{39}$ the government can use it any time at its own discretion, 40 and the Royal Commission on the Electoral System recommended its use for this electoral reform.

In Japan, some sorts of referendum are required by the Constitution. Article 96 requires a majority of popular votes for constitutional amendment after the initiation by the Diet with a majority of two-thirds of all the members of each House. ${ }^{41}$ Article 79, section 2 provides the popular votes for reviewing the appointment of the Justices of the Supreme Court. After the appointment by the Cabinet (in case of the Chief Justice, by the Emperor) and every ten years after that, the Justices have to be subjected to review by the people, and if a majority of votes goes against any of them, he or she is dismissed. ${ }^{42}$ Article 95 requires the consent of a majority of local voters, when the Diet enacts a special law applicable only to the local government. ${ }^{43}$

At the national level, referenda other than those provided by the Constitution have been totally nonexistent. Since article 41 provides that the Diet "shall be the sole lawmaking organ of the State," it is theoretically difficult for the people to be involved in enactment in other ways than provided in the Constitution, even when the referenda are not binding. Government officials have been especially critical about the idea of national referendum, and have claimed that once democratically elected representatives are chosen, parliamentary democracy requires that decisionmaking be made only by those elected, not by the electors themselves.

At the local level, there have been some indicative referenda about a locally critical issue, ${ }^{44}$ although they too are extremely rare and there is some ambiguity about their

39 The requirement of signatures of 10 percent of registered electors is so high that it does not seem that this type of referendum will be held so often. H Catt "The Other Democratic Experiment: New Zealand's Experience With Citizens' Initiated Referendum" (1996) 48 Political Science 29.

40 Above n 16, p 168.

41 The Constitution of Japan has not been amended since its promulgation in 1946.

42 There has been no Justice dismissed. All Justices have cleared those votes with wide margins. As a matter of fact, almost all Justices are appointed at sixty years old or older, so they are subjected to this review only once before their mandatory retirement at 70 .

43 Between 1949 and 1951, there were 15 popular votes under this provision, relating to city planning of particular cities. However, such a special law is extremely rare now.

44 Nine local governments have a special referendum ordinance on a specific issue. Five of them relates to construction of a nuclear power plant in that locality. In August 1996, at Maki town in 
legitimacy under the Local Self-Government Law, which does not authorise such a process of decisionmaking by local governments.

\section{CONCLUSION}

The electoral reform in Japan in 1994 was imperfect in terms of the constitutionally mandated equality of the value of votes. However, the Constitution of Japan relies much on the Diet itself for the reform, limiting the authority of the independent commission to just recommendations and excluding an involvement of the people. The comparison between electoral reforms in New Zealand and in Japan provides an opportunity to reexamine the characteristics of democratic process under the Constitution in Japan. Japan can learn something from the experience of New Zealand. Maybe Japanese electorate boundaries respect the integrity of prefectures too much. Maybe the tolerance of deviation from the strict "one person, one vote" principle can be further reduced by an explicit provision in the electoral law. Maybe some kind of referendum for an electoral reform can be used without violating the constitutional principle of parliamentary democracy. ${ }^{45}$

Is there anything New Zealand can learn from the experience of Japan? Almost all the problems in the electoral system in Japan seem to be resolved in New Zealand. However, if New Zealand considers the establishment of new upper house, ${ }^{46}$ the anomalous status of the House of Councillors in Japan suggests the need for caution in defining its structure according to its purpose.

From a perspective of comparative constitutional law, this comparison between recent electoral reforms in two democracies supplies a good example to show that the constitutional regime as well as political culture influences the approach and process of the reform. New Zealand could finalise a drastic electoral reform by popular referenda over the objections of quite a few politicians. The electoral reform in Japan was constrained by the supreme and sole lawmaking authority of the Diet and virtual exclusion of citizens from national policymaking under the Constitution.

Niigata prefecture, there was an indicative referendum about whether the town should convey its public land to an electric company for the construction of a nuclear power plant. In September 1996, in Okinawa prefecture (only prefecture which has such a referendum ordinance), there was an indicative referendum about the presence of the United States Armed Forces bases in that prefecture under the Japan-United States Security Treaty, although this was a policy matter of the national government rather than that of the prefecture government. $H$ Sakakibara, "Maki Machi Genpatsu Jumin-Tohyo to Jumin Sanka [Maki Town Nuclear Power Plant Referendum and Citizen Participation]" (1996) 41 Hogaku Seminar 22.

45 Even in Britain, where the principle of parliamentary sovereignty had been considered absolute, there were some referenda, including one about membership of the European Communities in 1975.

Above n 16, 280-282. 